\title{
Implementasi Interpolasi Fractal Untuk Pembesaran Skala Pada Citra Screen Capture CCTV
}

\author{
Putri Nurul Hasanah \\ Program Studi Teknik Informatika, STMIK Budi Darma, Medan, Indonesia \\ Email: putrinurul@gmail.com
}

Submitted 13-01-2020; Accepted 03-02-2020; Published 15-02-2020

\begin{abstract}
Abstrak
Berbagai jenis pengolahan citra yang dapat dilakukan oleh komputer saat ini seperti pembesaran citra, perbaikan kualitas citra dan penajaman suatu citra merupakan salah satu bidang yang cukup populer saat ini. Penajaman suatu citra ini sangatlah diperlukan agar seseorang dapat melihat dan mengamati dengan jelas objek citra tersebut dan tidak adanya gangguan. Suatu citra dapat memiliki gangguan kerusakan pada beberapa bagian atau blok pixel pada peroses pengiriman atau proses penyimpanan. Kerusakan ini adalah bentuk kesalahan utama pada citra, misalnya citra hasil Screen Capture CCTV. Masalah yang sering dihadapi saat kita ingin melihat sebuah rekaman CCTV adalah ketidak jelasannya suatu objek gambar yang ingin kita lihat. Apabila di Screen Capture dan di perbesar akan semakin tidak jelas objek gambar tersebut. Hasil citra Screen Capture ini memiliki tingkat ketajaman yang lebih baik jika dilakukan pembesaran terhadap citra tersebut secara langsung, biasanya Screen Capture ini dijadikan barang bukti dan lain sebagainya. Perbaikan citra ini dilakukan dengan proses operasi titik penyeleksian terhadap hasil gambar Screen Capture CCTV yang dijadikan sebagai sample. Setelah hasil penyeleksian hasil gambar Screen Capture didapat kemudian citra tersebut di Grayscale untuk menjadikan nilali pixel yang seragam, proses selanjutnya adalah proses pembesaran citra hasil gambar Screen Capture dengan cara penambahan pixel baru. Hal ini dilakukan dengan menyisipkan titik-titik pixel baru tersebut diantara titik-titik yang nilai pixel nya telah ditetapkan langsung dari citra asli. Untuk mengatasi permasalahan tersebut memerlukan metode Interpolasi Fractal untuk melakukan perbaikan pembesaran kualitas citra (image enhancement). Dengan metode ini diharapkan mampu untuk menyelesaikan masalah perbaikan pembesaran kualitas citra hasil gambar Screen Capture CCTV. Penelitian ini dilakukan untuk mengimplementasikan proses perbaikan perbesaran kualitas citra berdasarkan metode Interpolasi Fractal.
\end{abstract}

Kata Kunci: Interpolasi Fractal, Screen Capture CCTV, Perbaikan Citra, Pembesaran Kualitas Citra.

\begin{abstract}
Various types of image processing that can be done by computers today such as image enlargement, image quality improvement and sharpening of an image are one of the fields that are quite popular today. Sharpening an image is very necessary so that someone can see and observe clearly the object of the image and the absence of interference. An image can have damage to some parts or blocks of pixels in the sending or storage process. This damage is the main form of error in the image, for example the image of CCTV Capture. The problem that is often faced when we want to see a CCTV recording is the obscurity of an object image that we want to see. If the Screen Capture and zoom in will be increasingly unclear the image object. The results of this Screen Capture image have a better level of sharpness if it is enlarged directly, the Screen Capture is usually used as evidence and so on. This image improvement is done by the operation process of the selection point of the results of the CCTV Screen Capture image that is used as a sample. After the Screen Capture image selection results are obtained then the image is in Grayscale to make a uniform pixel value, the next process is the process of enlarging the image of the Screen Capture image by adding new pixels. This is done by inserting the new pixel points between the points where the pixel value has been set directly from the original image. To overcome these problems requires the Fractal Interpolation method to improve image quality enhancement. With this method it is expected to be able to solve the problem of improving the image quality enlargement of the results of the CCTV Capture Screen. This research was conducted to implement the process of improving image quality magnification based on the Fractal Interpolation method.
\end{abstract}

Keywords: Fractal Interpolation, CCTV Screen Capture, Image Repair, Image Quality Magnification.

\section{PENDAHULUAN}

Perkembangan teknologi di zaman sekarang sangatlah pesat, penggunaan kamera Closed Circuit Television (CCTV) pun sangatlah penting dalam kehidupan manusia saat ini, CCTV banyak digunakan di tempat seperti perusahaan, pertokoan, sekolah, jalan, dan lain-lain yang digunakan untuk keamanan atau sebagai kamera pemantau. Hasil dari rekaman video dari kamera CCTV tergantung dari fasilitas kualitas CCTV itu sendiri, ada yang bisa menangkap hasil dari ruang gelap atau sebaliknya. Serta pengaruh dari ruang atau area yang diletakkan kamera CCTV, apabila ruang tersebut banyak cahaya maka hasilnya rekaman CCTV kelihatan bagus, apabila ruangannya itu kurang menangkap cahaya maka hasil dari kamera CCTV hanya tampak objek yang terdapat cahaya, sehingga ada beberapa sisi objek yang kelihatan gelap. Salah satu prosesnya dapat dilakukan dengan pengolahan citra (image processing). Semakin canggihnya perangkat lunak maupun perangkat keras yang tersedia di zaman sekarang ini dan semakin banyaknya metode pengolahan citra yang ada, yang dulunya dapat menyebabkan proses pada pengolahan citra dilakukan secara manual menjadi berbasis komputerisasi.

Perbesaran citra harus mampu menghasilkan citra hasil perbesaran yang mempunyai kualitas yang baik yaitu tidak patah, mempunyai tekstur dan komposisi warna alami yaitu dengan tekstur dan komposisi warna yang sama dengan citra aslinya. Berbagai jenis pengolahan citra sekarang yang dapat dilakukan oleh komputer, seperti perbaikan kualitas citra (image enhancement) merupakan salah satu bidang yang cukup populer sekarang ini. Penajaman kualitas citra ini sangatlah diperlukan untuk memperbaiki aspek tampilan, agar seseorang dapat melihat dan mengamati citra tersebut dengan jelas dan tidak adanya gangguan seperti menggunakan image enchancement. Suatu citra dapat mengalami gangguan berupa kerusakan pada beberapa bagian atau blok pixel pada bagian proses pengiriman atau proses penyimpanan. Kerusakan ini adalah kerusakan utama yang sering di alami pada suatu citra, misalnya citra hasil Screen Capture. 
Screen Capture adalah merekam gambar yang diambil oleh pengguna layar komputer, tablet PC dan smartphone untuk melakukan record terhadap item yang ditampilkan oleh monitor atau visual output device yang lain. Hasil citra dari Screen Capture ini memiliki tingkat ketajaman dan kehalusan citra yang kecil, sehingga untuk mendapatkan citra yang lebih baik biasanya dilakukan pembesaran terhadap citra tersebut secara langsung, biasanya Screen Capture ini digunakan untuk mendemonstrasikan suatu program, biasanya dijadikan barang bukti dan lain sebagainya. Berdasarkan penelitian sebelumnya telah dilakukan perbaikan citra pada hasil pembesaran dengan kualitas yang terbaik dengan menggunakan metode Interpolasi fractal untuk perbaikan citra pembesaran Nilai skala vertikal 0 dapat menghasilkan kualitas citra pembesaran yang terbaik, semakin nilai vertikal nya menjauh dari 0 maka semakin rendah kualitas citra yang di hasilkan [1]. Melakukan penelitian dengan menggunakan metode Histogram Ekualisasi hasil dari Histogram Ekualisasi ini dilakukan image enhancement yang terdapat peningkatan pada nilai rata-rata intensitas pada citra Screen Capture CCTV yang dapat mengakibatkan citra uji coba 1 samapai citra uji coba 4 intensitas cahayanya menyebar dan untuk kontras citra ini juga mengalami peningkatan nilai kecerahan pada hasil citra Histogram Ekualisasi [2]. Melakukan penelitian menggunakan metode interpolasi linear pengubahan ukuran untuk menerapkan pembesaran resolusi citra sehingga ukuran citra lebih besar dari aslinya dengan menyisipkan titik diantara dua titik masukan yang telah tepat posisinya, data gambar yang berbentuk matrik dua dimensi ini dan dapat disimpan secara efektif dalam variabel yang bertipe larik [3]. Melakukan penelitian menggunakan metode Interpolasi Linier untuk perbaikan peningkatan resolusi citra dengan melakukan proses operasi titik pixel dengan penyeleksian terhadap hasil gambar Screenshot dengan cara penambahan pixel atau titik baru yang disisipkan titik-titik tersebut diantara titik-titik yang nilai pixelnya tetap dipetakan langsung dari citra aslinya [4].

Dalam mengatasi masalah tersebut perlu dilakukan langkah-langkah perbaikan kualitas gambar, salah satunya untuk mengatasi masalah tersebut adalah dengan menggunakan metode Interpolasi Fractal. Pada umumnya Interpolasi Fractal merupakan sebuah metode yang digunakan menentukan nilai dari variabel terikat untuk variabel bebas yang ditentukan berdasarkan suatu tabel yang menyajikan pasangan nilai variabel terikat dan variabel bebas, dalam hal ini hubungan matematis eksplisit antara variabel terikat dan variabel bebas tidak diketahui. Ada beberapa metode interpolasi, salah satunya adalah interpolasi fractal.

Berdasarkan hasil penelitian yang sudah dilakukan memberikan fakta bahwa penerapan metode Interpolasi fractal pada proses pembesaran citra dapat menghasilkan citra hasil pembesaran dengan kualitas yang terbaik dibandingkan dengan penggunaan metode Interpolasi lainnya khususnya untuk citra yang lebih sering berisi kan objek-objek alamiah seperti pohon, awan, hutan, jalan, bangunan dan lain sebagainya, metode Interpolasi fractal inilah yang lebih tepat untuk pembesaran cita pada Screen Capture CCTV.

\section{METODE PENELITIAN}

\subsection{Citra Digital}

Secara umum, pengolahan citra digital menunjuk pada pemrosesan gambar 2 dimensi menggunakan komputer. Dalam konteks yang lebih luas, pengolahan citra digital mengacu pada pemrosesan setiap data 2 dimensi. Citra digital merupakan sebuah larik (array) yang berisi nilai-nilai real maupun komplek yang direpresentasikan dengan deretan bit tertentu.

Suatu citra dapat didefinisikan sebagai fungsi $f(x, y)$ berukuran $\mathrm{M}$ baris dan $\mathrm{N}$ kolom, dengan $\mathrm{x}$ dan y adalah koordinat spasial, dan amplitudo $f$ di titik koordinat $(x, y)$ dinamakan intensitas atau tingkat keabuan dari citra pada titik tersebut [5]. Maka pada nilai x,y untuk keseluruhan dan nilai amplitudo $f$ yang berhingga dan bernilai diskrit dapat dikatakan citra digital.

\subsection{Interpolasi Fractal}

Kata fractal berasal dari kata lain fractus yang artinya pecah (broken) atau tidak teratur (irregular). Fractal pertama kali diperkenalkan oleh Benoit B Mandelbrot sekitar tahun 1977 dalam bukunya yang berjudul “ The Fractal Geometry Of Nature “. Fractal merupakan cara yang tepat untuk membuat pemodelan fenomena alam (natural phenomenon) dan dianggap sebagai alat yang andal untuk merepresentasikan objek-objek alam.

Banyak objek pada alam semesta ini memiliki model yang rumit dan tidak teratur. Sebagai contoh, pepohonan (trees), pengunungan (mountain), embun (clouds), sungai berliku-liku (river flows), garis pantai (coastline), permukaan tanah lapangan atau daerah (terrain), jaringan yang menyalurkan darah dari setiap sel ke seluruh tubuh atau sebaliknya, saraf retina mata, garis-garis telapak tangan, dan sebagainya. Seringkali terlihat objek-objek tersebut merupakan perulangan pola-pola pada berbagai skala, tidak masalah sekecil apapun ukuran skalanya. Pohon-pohonan memiliki cabang. Setiap cabang memiliki cabang lagi, dan demikian seterusnya. Perulangan tersebut terjadi tanpa batas hanya saja dalam skala yang lebih kecil [5].

Teori dan aplikasi interpolasi fractal ini sangat pesat perkembangannya matematikawan dari negara inggris Michael Bamsley menyajikan beberapa fungsi interpolasi bernilai real yang mendefinisikan pada interval tertutup dan terbatas R, yang secara khusus dirancang untuk mendekati fungsi yang terjadi secara alami dan memiliki kesamaan diri dalam interval kecil [6]. Fungsi-fungsi ini dibangun dengan cara mengkonsep diri dengan kesamaan yang tetap untuk sekala kecil, inilah yang membuat metode interpolasi fraktal ini berbeda dengan fungsi interpolasi klasik lainnya. Interpolasi merupakan sebuah metode yang digunakan menentukan nilai dari variabel terikat untuk variabel bebas yang ditentukan berdasarkan suatu tabel yang menyajikan pasangan nilai variabel terikat dan variabel bebas, dalam hal ini hubungan matematis eksplisit antara variabel terikat dan variabel bebas tidak diketahui. Ada beberapa metode interpolasi, salah satunya adalah interpolasi fractal. 
Fungsi interpolasi suatu data $\left\{\left(x_{i} F_{i}\right) € \mathrm{R}^{2}: i=0,1, \ldots, \mathrm{N}\right\}, x_{0}<x_{1}<x_{2}<\ldots x_{N}$, didefinisikan sebagai suatu kontinu $f:\left[x_{0}, x_{N}\right] \rightarrow \mathrm{R}$ sehingga $f\left(x_{i}\right)=F_{i}$ untuk $i=0,1, \ldots ., \mathrm{N}$. Titik-titik $\left(x_{i} F_{i}\right) € \mathrm{R}^{2}$ untuk $i=0,1, \ldots ., \mathrm{N}$ disebut titik-titik interpolasi dan dikatakan bahwa fungsi $f$ menginterpolasikan data tersebut [9].

Dalam pembahasan interpolasi fraktal akan dikontruksikan suatu $\operatorname{SFI}\left\{\mathrm{R}^{2}: \mathrm{w}_{\mathrm{n}}, \mathrm{n}=1,2, \ldots ., \mathrm{N}\right\}$ sehingga eksistensi atraktornya terjamin dan merupakan grafik dari suatu fungsi kontinu $f:\left[x_{0}, x_{N}\right] \rightarrow \mathrm{R}$ yang menginterpolasikan data $\left\{\left(x_{i} F_{i}\right)\right.$ $\left.€ \mathrm{R}^{2}: i=0,1, \ldots, \mathrm{N}\right\}$. Disini dipilih suatu SFI $\left\{\mathrm{R}^{2}: \mathrm{W}_{\mathrm{n}}, \mathrm{n}=1,2, \ldots ., \mathrm{N}\right\}$, dengan $\mathrm{w}_{\mathrm{n}}$ teranformasi affine yang terbentuk khusus, i.e. Metode yang digunakan dalam penelitian ini adalah metode eksperimen dengan langkah-langkah sebagai berikut :

1. Formulasi interpolasi fractal berbentuk

$F_{i}\left(\begin{array}{l}x \\ y\end{array}\right)=\left(\begin{array}{l}x^{\prime} \\ y^{\prime}\end{array}\right)=\left(\begin{array}{cc}a_{i} & 0 \\ b_{i} & c_{i}\end{array}\right)\left(\begin{array}{l}x \\ y\end{array}\right)+\left(\begin{array}{l}d_{i} \\ e_{i}\end{array}\right), i=1,2, \ldots, n-1$ dan $\left|c_{i}\right|<1$

Dengan

$a_{i}=\frac{x_{i+1}-x_{i}}{x_{n}-x_{1}}$

$d_{i}=\frac{x_{n} x_{i}-x_{1} x_{i+1}}{x_{n}-x_{1}}$

$b_{i}=\frac{y_{i+1}-y_{i}-c_{i}\left(y_{n}-y_{1}\right)}{x_{n}-x_{1}}$

$e_{i}=\frac{x_{n} y_{i}-x_{1} y_{i+1}-c_{i}\left(x_{n} y_{1}-x_{1} y_{n}\right)}{x_{n}-x_{1}}\left|c_{i}\right|<1$ disebut skala vertikal

Keterangan :

$F_{i} \quad=$ Nilai pixel baru

$a_{i} \quad=$ Nilai skala horizontal

$d_{i} \quad=$ Nilai matriks ke $i$

$b_{i} \quad=$ Nilai skala vertikal

$e_{i} \quad=$ Nilai matriks ke $i$

$c_{i} \quad=$ Nilai skala vertikal

$x=$ Nilai koordinat spacial $x$

$y \quad=$ Nilai koordinat spacial $y$

$n \quad=$ Nilai suku ke $x$ yang dicari

Berdasarkan formula interpolasi fractal tersebut diatas peneliti yakin bahwa nilai skala vertikal $c_{i}$ akan berpengaruh terhadap kualitas dari citra hasil pembesaran. Dari formula interpolasi fractal tersebut, bisa kita ketahui bahwa nilai skala berpengaruh terhadap nilai pixel (yaitu komponen y' pada formula interpolasi fractal ), yang mana semakin besar nilai sekala vertikalnya maka nilai pixel juga akan semakin besar.

Untuk cara kerjanya sendiri interpolasi fraktal sangat berguna terutama untuk proses pembesaran yang ekstrim. Dengan algoritma interpolasi fraktal akan dihasilkan citra hasil pembesaran yang sangat mendekati sempurna. Pada umumnya algoritma fraktal akan sangat efisien jika objek yang diolah adalah objek yang memiliki bentuk dan kontur yang walaupun rumit tetapi memiliki karakteristik khusus misalnya objek-objek natural yaitu awan, gunung, lautan dan pepohonan [7].

\subsection{CCTV (Closed Circuit Television)}

CCTV merupakan singkatan dari Closed Circuit Television, dimana berfungsi sebagai aplikasi kamera pengawas dari jarak jauh. Mengapa disebut closed circuit? Karena CCTV menggunakan sirkuit tertutup, yang artinya CCTV ini terbuka hanya pada jaringan tertentu dan IP tertentu [8]. CCTV merekam semua sistem pengawasan dengan monitoring pada suatu kawasan yang menggunakan satu atau lebih kamera video yang dipasang ditempat-tempat tertentu yang menghasilkan data video ataupun audio dan dipantau dari sebuah ruangan kontrol.

Penggunaan kamera CCTV ini banyak digunakan di lokasi atau tempat umum seperti di perusahaan, pertokoan, sekolah, jalan, dan lain-lain untuk keamanan atau sebagai kamera pemantau. Hasil dari rekaman video CCTV ini tergantung dari fasillitas dan kualitas kamera itu sendiri, ada yang bisa menangkap hasil dari ruangan yang gelap dan sebaliknya. Serta pengaruh dari ruangan atau area yang diletakkan kamera CCTV, apabila ruangan tersebut banyak menangkap cahaya maka hasil rekaman CCTV kelihatan bagus, dan sebaliknya apabila ruangan tersebut itu kurang menangkap cahaya maka hasil rekaman dari kamera CCTV itu hanya tampak objek-objek yang hanya terdapat cahaya sehingga ada beberapa sisi objek yang kelihatan gelap.

\section{ANALISA DAN PEMBAHASAN}

Proses perbaikan citra hasil gambar Screen Capture dilakukan dengan cara melakukan proses operasi titik penyeleksian terhadap hasil gambar Screen Capture yang dijadikan sebagai sampel. Setelah hasil penyeleksian hasil gambar Screen Capture di dapat maka, proses selanjutnya adalah proses pembesaran citra hasil gambar Screen Capture dengan cara penambahan pixel atau titik baru ini dilakukan dengan menyisipkan titik-titik tersebut diantara titik-titik yang nilai pixel telah tetap yang dipetakan langsung dari citra asli. Pixel yang ada didalam citra masukan tersebut berisi informasi warna atau intensitas warna RGB yang penting untuk menaksir intensitas warna dari pixel yang masih kosong pada citra. Nilai tiap pixel, pada gambar dapat diketahui dari seluruh nilai pixel tersimpan sesuai koordinatnya dan memudahkan untuk proses perbaikan citra. Proses tersebut bertujuan untuk menghasilkan citra resolusi tinggi dengan memaksimalkan nilai kepadatan 
pixel pada citra melalui proses observasi terhadap citra yang memiliki resolusi rendah berdasakan letak dan nila pixel masingmasing citra yang dibuat menjadi citra tunggal untuk membentuk citra resolusi tinggi. Proses pembesaran bertujuan untuk meningkatkan resolusi dari suatu citra, karena semakin besar skala citra maka akan semakin detail objek yang tampak pada citra tersebut. Pada proses perbaikan citra hasil dari Screen Capture ini memiliki kapasitas citra ukuran gambar yang kecil dan dapat diperbaiki dengan melakukan proses pembesaran citra agar memiliki resolusi ynag baik dan tidak pecah, serta dapat menungkatkan resolusi dari suatu citra, karena semakin besar skala citra maka akan semakin detail objek yang tampak pada citra tersebut.

Perbaikan citra hasil gambar Screen Capture dapat diperbaiki dengan salah satu metode perbaikan citra yaitu, interpolasi fractal dimana hasil pembesaran citra dilakukan di dalam objek jpg dan resolusi akan bertambah setelah proses pembesaran dilakukan pada gambar masukan. Proses penambahan pixel baru ini dilakukan dengan menyisipkan titiktitik tersebut diantara titik-titik yang harganya telah tetap yang dipetakan langsung dari citra asli. Pixel yang ada dalam citra masukan tersebut berisi informasi intensitas warna RGB untuk menaksir intensitas warna dari pixel yang masih kosong pada citra objek jpg. Proses interpolasi fractal menentukan nilai dari variabel terikat untuk variabel bebas yang ditentukan berdasarkan suatu tabel yang menyajikan pasangan nilai variabel terikat dan variabel bebas.

\subsection{Penerapan Metode Interpolasi Fractal Pada Perbaikan Pembesaran Citra Hasil Screen Capture}

Proses pembesaran citra ini dilakukan dalam objek jpg dan resolusi akan bertambah setelah proses pembesaran dilakukan padagambar masukan. Proses penambahan pixel atau titik baru ini dilakukan dengan menyisipkan titik-titik tersebut diantara titik-titik yang harganya telah tetap yang dipetakan langsung dari citra asli. Citra input hasil gambar Screen Capture yang digunakan untuk memahami proses penyelesaian metode intrpolasi fractal adalah sebagai berikut :

1. Melakukan Screen Capture dari objek gambar layar monitor. Gambar Screen Capture dan gambar hasil sleksi Screen Capture.

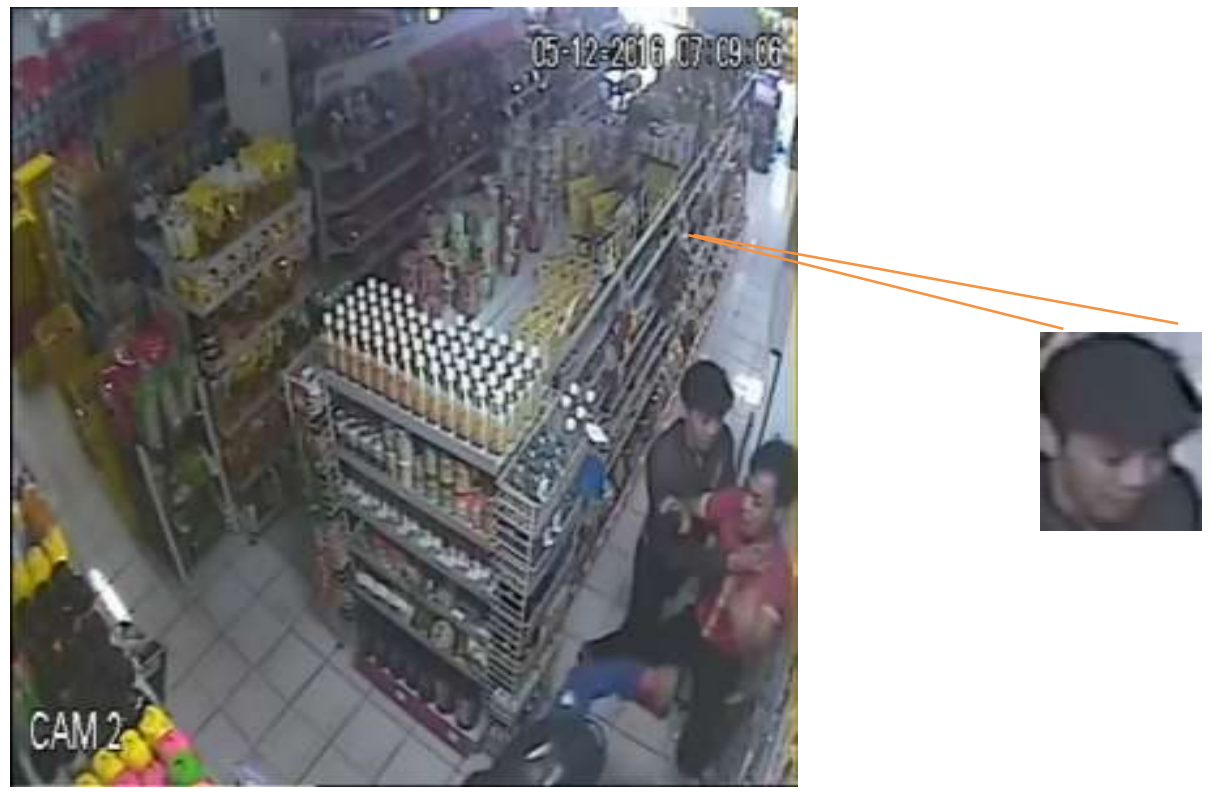

Gambar 1. Objek Citra yang di Screen Capture

2. Menyeleksi gambar Screen Capture

Gambar yang digunakan adalah gambar wajah seseorang yang tengah mencuri toko swalayan tersebut yang memiliki pixel 20x20 namun hanya sebagian gambar dari gambar wajah tersebut dengan nilai pixel 10x10 dan dilakukan pembesaran 2 kali maka proses dari metode interpolasi fractal adalah sebagai berikut :
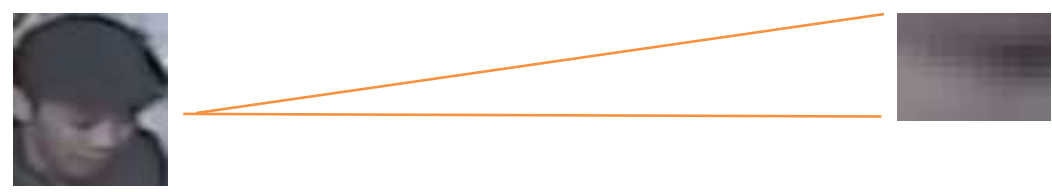

Gambar 2. (a) Gambar Hasil Seleksi Screen Caputre, (b) Gambor Contoh Perhitungan Metode Interpolasi Fractal

3. Mencari nilai pixel menggunakan aplikasi Matlab ada pun perintah fungsi matlabnya adalah sebagai berikut :

input_gambar = input('Input Gambar');

gambar = imread (input_gambar);

nilai_red = gambar $(:,:, 1)$;

nilai_green = gambar $(:,:, 2)$;

nilai_blue = gambar $(:,:, 3)$;

disp(nilai_red));

disp(nilai_green)); 
disp(nilai_blue));

Tabel 1. Pixel Nilai R

\begin{tabular}{llllllllll}
\hline \multicolumn{10}{c}{ Nilai R } \\
\hline 90 & 87 & 79 & 74 & 70 & 67 & 68 & 69 & 69 & 69 \\
88 & 84 & 78 & 73 & 70 & 67 & 68 & 69 & 69 & 69 \\
83 & 80 & 75 & 72 & 70 & 68 & 69 & 70 & 69 & 69 \\
78 & 76 & 73 & 70 & 70 & 68 & 70 & 71 & 69 & 69 \\
74 & 73 & 71 & 70 & 70 & 69 & 70 & 71 & 70 & 70 \\
71 & 70 & 69 & 70 & 70 & 69 & 70 & 71 & 70 & 70 \\
69 & 69 & 69 & 70 & 71 & 70 & 71 & 71 & 70 & 70 \\
68 & 69 & 69 & 70 & 71 & 70 & 71 & 71 & 70 & 70 \\
68 & 69 & 70 & 70 & 71 & 71 & 71 & 71 & 72 & 72 \\
68 & 69 & 70 & 70 & 71 & 71 & 71 & 71 & 72 & 72 \\
\hline
\end{tabular}

Tabel 2. Pixel Nilai G

\begin{tabular}{llllllllll}
\hline \multicolumn{10}{c}{ Nilai G } \\
\hline 84 & 80 & 74 & 69 & 65 & 64 & 65 & 66 & 68 & 68 \\
82 & 77 & 73 & 68 & 65 & 64 & 65 & 66 & 68 & 68 \\
77 & 73 & 70 & 67 & 65 & 65 & 66 & 67 & 68 & 68 \\
72 & 69 & 68 & 65 & 65 & 65 & 67 & 68 & 68 & 68 \\
68 & 66 & 66 & 65 & 65 & 66 & 67 & 68 & 69 & 69 \\
65 & 63 & 64 & 65 & 65 & 66 & 67 & 68 & 69 & 69 \\
63 & 62 & 64 & 65 & 66 & 67 & 68 & 68 & 69 & 69 \\
62 & 62 & 64 & 65 & 66 & 67 & 68 & 68 & 69 & 69 \\
63 & 64 & 65 & 67 & 68 & 70 & 70 & 70 & 71 & 71 \\
63 & 64 & 65 & 67 & 68 & 70 & 70 & 70 & 71 & 71 \\
\hline
\end{tabular}

Tabel 3. Pixel Nilai B

\begin{tabular}{llllllllll}
\hline \multicolumn{10}{c}{ Nilai B } \\
\hline 88 & 87 & 80 & 75 & 72 & 71 & 74 & 75 & 74 & 74 \\
86 & 84 & 79 & 74 & 72 & 71 & 74 & 75 & 74 & 74 \\
81 & 80 & 76 & 73 & 72 & 72 & 75 & 76 & 74 & 74 \\
76 & 76 & 74 & 71 & 72 & 72 & 76 & 77 & 74 & 74 \\
72 & 73 & 72 & 71 & 72 & 73 & 76 & 77 & 75 & 75 \\
69 & 70 & 70 & 71 & 72 & 73 & 76 & 77 & 75 & 75 \\
67 & 69 & 70 & 71 & 73 & 74 & 77 & 77 & 75 & 75 \\
66 & 69 & 70 & 71 & 73 & 74 & 77 & 77 & 75 & 75 \\
70 & 71 & 72 & 74 & 75 & 76 & 76 & 76 & 77 & 77 \\
70 & 71 & 72 & 74 & 75 & 76 & 76 & 76 & 77 & 77 \\
\hline
\end{tabular}

4. Pembentukan pembesaran matrik.

Maka hasil height dan width adalah 20x20, sedangkan untuk memetakan intensitas warna RGB yang ada pada citra asli ke warna citra pada jpg, untuk pixel dengan posisi 0 maka, pixel terakhir (height-1) dan (Width-1) akan dipetakan ke posisi yang sama pada jpg, hal ini penting agar tidak terjadi pixel sisa yang tidak berguna atau menyebabkan kerusakan gambar. Gambar citra Screen Capture ini akan di ubah dari RGB ke Grayscale karena ini akan sangat membantu memanipulasi bit yang tidak terlalu banyak sehingga nilai akhir hasil height dan width adalah 19x19 dan memiliki nilai matriknya adalah sebagai berikut :

Tabel 4. Nilai Matriks Pembesaran Citra

\begin{tabular}{llllllllll}
\hline 86 & 83 & 76 & 71 & 67 & 66 & 67 & 68 & 69 & 69 \\
\hline 84 & 80 & 75 & 70 & 67 & 66 & 67 & 68 & 69 & 69 \\
79 & 76 & 72 & 69 & 67 & 67 & 68 & 69 & 69 & 69 \\
74 & 72 & 70 & 67 & 67 & 67 & 69 & 70 & 69 & 69 \\
70 & 69 & 68 & 67 & 67 & 68 & 69 & 70 & 70 & 70 \\
67 & 66 & 66 & 67 & 67 & 68 & 69 & 70 & 70 & 70 \\
65 & 65 & 66 & 67 & 68 & 69 & 70 & 70 & 70 & 70 \\
64 & 65 & 66 & 67 & 68 & 69 & 70 & 70 & 70 & 70 \\
65 & 66 & 67 & 69 & 70 & 71 & 71 & 71 & 72 & 72 \\
\hline
\end{tabular}




\begin{tabular}{llllllllll}
\hline 65 & 66 & 67 & 69 & 70 & 71 & 71 & 71 & 72 & 72 \\
\hline
\end{tabular}

5. Proses mencari nilai pixel yang kosong menerapkan metode Interpolasi Fractal :

$$
\begin{aligned}
& a_{i}=\frac{83-86}{83-86}=0 \\
& b_{i}=\frac{83-86-2(83-86)}{83-86}=-2(-3)=6 \\
& d_{i}=\frac{83 \times 86-83 \times 86}{83-86}=\frac{0}{-3}=0 \\
& e_{i}=\frac{83 \times 86-86 \times 83-2(83 \times 86-86 \times 83)}{83 \times 86}=\frac{0}{-3}=0 \\
& F_{i}\left(\begin{array}{l}
x \\
y
\end{array}\right)=\left(\frac{x^{\prime}}{y^{\prime}}\right)=\left(\begin{array}{ll}
a_{i} & 0 \\
b_{i} & c_{i}
\end{array}\right)\left(\begin{array}{l}
x \\
y
\end{array}\right)+\left(\begin{array}{l}
d_{i} \\
e_{i}
\end{array}\right) \\
& =\left(\begin{array}{ll}
0 & 0 \\
6 & 2
\end{array}\right)\left(\begin{array}{l}
83 \\
86
\end{array}\right)+\left(\begin{array}{l}
0 \\
0
\end{array}\right) \\
& =\left(\begin{array}{cc}
0 & 0 \\
498 & 172
\end{array}\right)=\left(\begin{array}{l}
172 \\
243
\end{array}\right)=\left(\begin{array}{c}
86 \\
121
\end{array}\right) \\
& a_{i}=\frac{69-69}{69-69}=0 \\
& b_{i}=\frac{69-69-2(69-69)}{69-69}=-2(0)=0 \\
& d_{i}=\frac{69 \times 69-69 \times 69}{69-69}=\frac{0}{0}=0 \\
& e_{i}=\frac{69 \times 68-68 \times 69-2(69 \times 68-68 \times 69)}{69-69}=\frac{0}{0}=0 \\
& F_{i}\left(\begin{array}{l}
x \\
y
\end{array}\right)=\left(\frac{x^{\prime}}{y^{\prime}}\right)=\left(\begin{array}{cc}
a_{i} & 0 \\
b_{i} & c_{i}
\end{array}\right)\left(\begin{array}{l}
x \\
y
\end{array}\right)+\left(\begin{array}{c}
d_{i} \\
e_{i}
\end{array}\right) \\
& =\left(\begin{array}{ll}
0 & 0 \\
0 & 2
\end{array}\right)\left(\begin{array}{l}
69 \\
69
\end{array}\right)+\left(\begin{array}{l}
0 \\
0
\end{array}\right) \\
& =\left(\begin{array}{cc}
0 & 0 \\
0 & 138
\end{array}\right)=\left(\begin{array}{c}
138 \\
0
\end{array}\right)=\left(\begin{array}{c}
69 \\
0
\end{array}\right)
\end{aligned}
$$

Hasil matriks pembesaran adalah sebagai berikut :

Tabel 5. Nilai Matriks Hasil Pembesaran Citra

\begin{tabular}{ccccccccccccccccccc}
\hline 86 & 86 & 83 & 83 & 76 & 76 & 71 & 71 & 67 & 67 & 66 & 66 & 67 & 67 & 68 & 68 & 69 & 69 & 69 \\
\hline 86 & 121 & 83 & 149 & 76 & 100 & 71 & 140 & 67 & 66 & 66 & 67 & 67 & 68 & 68 & 69 & 69 & 0 & 69 \\
84 & 84 & 80 & 80 & 75 & 75 & 70 & 70 & 67 & 67 & 66 & 66 & 67 & 67 & 68 & 68 & 69 & 69 & 69 \\
84 & 192 & 80 & 120 & 75 & 95 & 70 & 73 & 67 & 66 & 66 & 67 & 67 & 68 & 68 & 69 & 69 & 0 & 69 \\
79 & 79 & 76 & 76 & 72 & 72 & 69 & 69 & 67 & 67 & 67 & 67 & 68 & 68 & 69 & 69 & 69 & 69 & 69 \\
79 & 100 & 76 & 160 & 72 & 79 & 69 & 67 & 67 & 0 & 67 & 68 & 68 & 69 & 69 & 0 & 69 & 0 & 69 \\
74 & 74 & 72 & 72 & 70 & 70 & 67 & 67 & 67 & 67 & 67 & 67 & 69 & 69 & 70 & 70 & 69 & 69 & 69 \\
74 & 72 & 72 & 70 & 70 & 73 & 67 & 0 & 67 & 0 & 67 & 69 & 69 & 70 & 70 & 69 & 69 & 0 & 69 \\
70 & 70 & 69 & 69 & 68 & 68 & 67 & 67 & 67 & 67 & 68 & 68 & 69 & 69 & 70 & 70 & 70 & 70 & 70 \\
70 & 69 & 69 & 68 & 68 & 67 & 67 & 0 & 67 & 68 & 68 & 69 & 69 & 70 & 70 & 0 & 70 & 0 & 70 \\
67 & 67 & 66 & 66 & 66 & 66 & 67 & 67 & 67 & 67 & 68 & 68 & 69 & 69 & 70 & 70 & 70 & 70 & 70 \\
67 & 66 & 66 & 0 & 66 & 67 & 67 & 0 & 67 & 68 & 68 & 69 & 69 & 70 & 70 & 0 & 70 & 0 & 70 \\
65 & 65 & 65 & 65 & 66 & 66 & 67 & 67 & 68 & 68 & 69 & 69 & 70 & 70 & 70 & 70 & 70 & 70 & 70 \\
65 & 0 & 65 & 66 & 66 & 67 & 67 & 68 & 68 & 69 & 69 & 70 & 70 & 0 & 70 & 0 & 70 & 0 & 70 \\
64 & 64 & 65 & 65 & 66 & 66 & 67 & 67 & 68 & 68 & 69 & 69 & 70 & 70 & 70 & 70 & 70 & 70 & 70 \\
64 & 65 & 65 & 66 & 66 & 67 & 67 & 68 & 68 & 69 & 69 & 70 & 70 & 0 & 70 & 0 & 70 & 0 & 70 \\
65 & 65 & 66 & 66 & 67 & 67 & 69 & 69 & 70 & 70 & 71 & 71 & 71 & 71 & 71 & 71 & 72 & 72 & 72 \\
65 & 66 & 66 & 67 & 67 & 69 & 69 & 70 & 70 & 71 & 71 & 0 & 71 & 0 & 71 & 72 & 72 & 0 & 72 \\
65 & 65 & 66 & 66 & 67 & 67 & 69 & 69 & 70 & 70 & 71 & 71 & 71 & 71 & 71 & 71 & 72 & 72 & 72 \\
\hline
\end{tabular}

Berdasarkan hasil matriks pembesarran citra di atas, dapat disimpulkan bahwa nilai pixel-pixel yang dicari memiliki ukuran citra lebih besar dari hasilnya serta memiliki resolusi yang lebih besar dari citra awal. Dapat dilihat perbandingan citra awal dan citra hasil dibawah ini :

Tabel 6. Resolusi 10x10

\begin{tabular}{llllllllll}
\hline 86 & 83 & 76 & 71 & 67 & 66 & 67 & 68 & 69 & 69 \\
\hline 84 & 80 & 75 & 70 & 67 & 66 & 67 & 68 & 69 & 69 \\
79 & 76 & 72 & 69 & 67 & 67 & 68 & 69 & 69 & 69 \\
74 & 72 & 70 & 67 & 67 & 67 & 69 & 70 & 69 & 69 \\
70 & 69 & 68 & 67 & 67 & 68 & 69 & 70 & 70 & 70 \\
67 & 66 & 66 & 67 & 67 & 68 & 69 & 70 & 70 & 70 \\
65 & 65 & 66 & 67 & 68 & 69 & 70 & 70 & 70 & 70 \\
64 & 65 & 66 & 67 & 68 & 69 & 70 & 70 & 70 & 70 \\
\hline
\end{tabular}


Tabel 7. Resolusi 19x19

\begin{tabular}{lllllllllllllllllll}
\hline 86 & 84 & 82 & 78 & 74 & 70 & 67 & 66 & 65 & 65 & 65 & 66 & 66 & 66 & 67 & 67 & 69 & 68 & 67 \\
\hline 90 & 89 & 86 & 83 & 79 & 75 & 72 & 71 & 68 & 68 & 69 & 69 & 69 & 70 & 70 & 70 & 74 & 73 & 72 \\
86 & 85 & 82 & 79 & 75 & 72 & 69 & 68 & 66 & 66 & 66 & 66 & 67 & 67 & 67 & 68 & 70 & 69 & 69 \\
80 & 79 & 76 & 73 & 70 & 67 & 65 & 64 & 64 & 64 & 65 & 65 & 65 & 66 & 66 & 66 & 66 & 65 & 64 \\
81 & 80 & 78 & 75 & 72 & 70 & 68 & 67 & 68 & 68 & 68 & 69 & 69 & 69 & 70 & 70 & 69 & 69 & 68 \\
79 & 78 & 76 & 74 & 72 & 70 & 68 & 68 & 66 & 67 & 67 & 67 & 68 & 68 & 68 & 68 & 71 & 70 & 69 \\
74 & 74 & 72 & 70 & 69 & 67 & 65 & 65 & 64 & 64 & 64 & 65 & 65 & 65 & 66 & 66 & 69 & 69 & 68 \\
74 & 74 & 72 & 71 & 69 & 67 & 66 & 66 & 67 & 67 & 68 & 68 & 68 & 69 & 69 & 69 & 71 & 70 & 69 \\
70 & 70 & 69 & 68 & 67 & 67 & 67 & 68 & 66 & 66 & 67 & 68 & 68 & 69 & 70 & 70 & 72 & 71 & 70 \\
69 & 69 & 68 & 67 & 66 & 66 & 67 & 67 & 66 & 66 & 67 & 68 & 68 & 69 & 70 & 70 & 72 & 71 & 70 \\
67 & 67 & 66 & 65 & 65 & 65 & 65 & 66 & 66 & 66 & 67 & 68 & 68 & 69 & 70 & 70 & 72 & 71 & 70 \\
65 & 65 & 64 & 64 & 63 & 64 & 64 & 65 & 66 & 66 & 67 & 68 & 68 & 69 & 70 & 70 & 72 & 71 & 70 \\
64 & 64 & 63 & 63 & 63 & 63 & 64 & 65 & 66 & 66 & 67 & 68 & 68 & 69 & 70 & 70 & 72 & 71 & 70 \\
63 & 63 & 63 & 62 & 63 & 63 & 64 & 65 & 66 & 66 & 67 & 68 & 68 & 69 & 70 & 70 & 72 & 71 & 70 \\
63 & 63 & 63 & 63 & 63 & 64 & 65 & 66 & 66 & 66 & 67 & 68 & 68 & 69 & 70 & 70 & 72 & 71 & 70 \\
63 & 63 & 63 & 63 & 64 & 65 & 66 & 66 & 66 & 66 & 67 & 68 & 68 & 69 & 70 & 70 & 72 & 71 & 70 \\
67 & 67 & 67 & 68 & 68 & 68 & 69 & 69 & 66 & 67 & 67 & 68 & 69 & 69 & 68 & 68 & 73 & 72 & 71 \\
71 & 72 & 72 & 72 & 73 & 73 & 73 & 73 & 71 & 72 & 73 & 74 & 74 & 74 & 74 & 73 & 77 & 77 & 76 \\
67 & 68 & 68 & 68 & 69 & 69 & 69 & 69 & 68 & 69 & 70 & 71 & 71 & 71 & 71 & 71 & 73 & 73 & 72 \\
\hline
\end{tabular}

\subsection{Pembesaran Citra Screen Capture CCTV}

Pengujian dalam perbaikan citra sangat diperlukan karena dengan adanya pengujian kita dapat mengetahui perbaikan pembesaran citra ini. Pengujian perbaikan citra yang akan diuji merupakan perbaikan citra hasil Screen Capture yang berbasis jpg, dimana perbaikan citra tersebut akan dijalankan pada sistem operasi windows yang mendukung jpg. Melihat hasil dari pembesaran yang akan dijalankan, dapat menggunakan Matlab R2017a sehingga dalam proses pengujian dalam perbaikan citra tersebut akan dapat dilihat kekurangan dan kelebihan pada hasil Screen Capture tersebut sebelum dijalankan langsung pada sistem operasi windows.

Perbandingan atara gambar citra awal dengan citra hasil dapat diketahui dari perhitungan Mean Square Error (MSE) dan Peak Signal-to-Noise Ratio (PSNR) pada citra digital ini merupakan suatu contoh parameter yang dapat digunakan sebagai indikator gunanya untuk mengukur kemiripan dua buah citra. Parameter ini sering digunakan untuk membandingkan citra hasil perbaikan kualitas citra dengan citra asli. PSNR ini adalah perbandingan atara nilai maksimum dari sinyal yang diukur dengan besarnya derau yang berpengaruh pada sinyal tersebut. Sedangakan untuk MSE itu sendiri adalah nilai error kuadrat rata-rata antara citra asli dengan citra hasil penyisipan. Untuk menentukan nilai PSNR terlebih dahulu harus menentukan nilai MSE nya. Berikut ini adalah gambar citra awal dan gambar citra hasil :

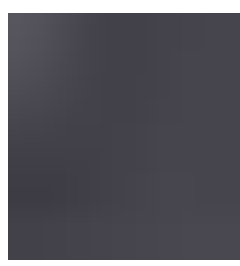

a

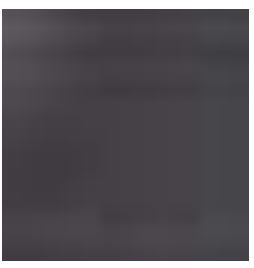

b

Gambar 3. (a) Gambar Citra Awal Pembesaran Screen Capture, (b) Gambar Citra Hasil Perbaikan Pembesaran Screen Capture

1. Mencari nilali MSE untuk metode interpolasi fractal dengan menggunakan citra asli dan citra hasil yang sudah diperbaiki

\begin{tabular}{llllllllllllllllllll}
\hline 86 & 83 & 76 & 71 & 67 & 66 & 67 & 68 & 69 & 69 & 86 & 84 & 82 & 78 & 74 & 70 & 67 & 66 & 65 & 65 \\
\hline 84 & 80 & 75 & 70 & 67 & 66 & 67 & 68 & 69 & 69 & 90 & 89 & 86 & 83 & 79 & 75 & 72 & 71 & 68 & 68 \\
79 & 76 & 72 & 69 & 67 & 67 & 68 & 69 & 69 & 69 & 86 & 85 & 82 & 79 & 75 & 72 & 69 & 68 & 66 & 66 \\
74 & 72 & 70 & 67 & 67 & 67 & 69 & 70 & 69 & 69 & 80 & 79 & 76 & 73 & 70 & 67 & 65 & 64 & 64 & 64 \\
70 & 69 & 68 & 67 & 67 & 68 & 69 & 70 & 70 & 70 & 81 & 80 & 78 & 75 & 72 & 70 & 68 & 67 & 68 & 68 \\
67 & 66 & 66 & 67 & 67 & 68 & 69 & 70 & 70 & 70 & 79 & 78 & 76 & 74 & 72 & 70 & 68 & 68 & 66 & 67 \\
65 & 65 & 66 & 67 & 68 & 69 & 70 & 70 & 70 & 70 & 74 & 74 & 72 & 70 & 69 & 67 & 65 & 65 & 64 & 64 \\
64 & 65 & 66 & 67 & 68 & 69 & 70 & 70 & 70 & 70 & 74 & 74 & 72 & 71 & 69 & 67 & 66 & 66 & 67 & 67 \\
65 & 66 & 67 & 69 & 70 & 71 & 71 & 71 & 72 & 72 & 70 & 70 & 69 & 68 & 67 & 67 & 67 & 68 & 66 & 66 \\
\hline
\end{tabular}




\begin{tabular}{rrrrllllllllllllllll}
\hline 65 & 66 & 67 & 69 & 70 & 71 & 71 & 71 & 72 & 72 & 69 & 69 & 68 & 67 & 66 & 66 & 67 & 67 & 66 & 66 \\
\hline \multicolumn{1}{c}{ Citra Awal } & & & \multicolumn{1}{c}{ Citra Hasil } & & &
\end{tabular}

Penyelesaian :

$\mathrm{MSE}=(86-86)^{2}+(83-84)^{2}+(76-82)^{2}+(71-78)^{2}+(67-74)^{2}+(66-70)^{2}+(67-67)^{2}+(68-$
$66)^{2}+(69-65)^{2}+(69-65)^{2}+(84-90)^{2}+(80-89)^{2}+(75-86)^{2}+(70-83)^{2}+(67-79)^{2}+(66-$
$75)^{2}+(67-72)^{2}+(68-71)^{2}+(69-68)^{2}+(69-68)^{2}+(79-86)^{2}+(76-85)^{2}+(72-82)^{2}+(69-$
$79)^{2}+(67-75)^{2}+(67-72)^{2}+(68-69)^{2}+(69-68)^{2}+(69-66)^{2}+(69-66)^{2}+(74-80)^{2}+(72-$
$79)^{2}+(70-76)^{2}+(67-73)^{2}+(67-70)^{2}+(67-67)^{2}+(69-65)^{2}+(70-64)^{2}+(69-64)^{2}+(69-$
$64)^{2}+(70-81)^{2}+(69-80)^{2}+(68-78)^{2}+(67-75)^{2}+(67-72)^{2}+(68-70)^{2}+(69-68)^{2}+(70-$
$67)^{2}+(70-68)^{2}+(70-68)^{2}+(67-79)^{2}+(66-78)^{2}+(66-76)^{2}+(67-74)^{2}+(67-72)^{2}+(68-$
$70)^{2}+(69-68)^{2}+(70-68)^{2}+(70-66)^{2}+(70-67)^{2}+(65-74)^{2}+(65-74)^{2}+(66-72)^{2}+(67-$
$70)^{2}+(68-69)^{2}+(69-67)^{2}+(70-65)^{2}+(70-64)^{2}+(70-64)^{2}+(64-74)^{2}+(65-74)^{2}+(66-$
$72)^{2}+(67-71)^{2}+(68-69)^{2}+(69-67)^{2}+(70-77)^{2}+(70-66)^{2}+(70-67)^{2}+(70-67)^{2}+(65-$
$70)^{2}+(66-70)^{2}+(67-69)^{2}+(69-68)^{2}+(70-67)^{2}+(71-67)^{2}+(71-67)^{2}+(71-68)^{2}+(72-$
$66)^{2}+(72-66)^{2}+(65-69)^{2}+(66-69)^{2}+(67-68)^{2}+(69-67)^{2}+(70-66)^{2}+(71-66)^{2}+(71-$
$67)^{2}+(71-67)^{2}+(72-66)^{2}+(72-66)^{2}$

$\mathrm{MSE}=$

$0+1+36+49+49+16+0+4+16+16+36+81+121+169+144+81+25+9+1$

$+1+49+81+100+100+64+25+1+1+9+9+36+49+36+36+9+0+16+36$

$+25+25+121+121+100+64+25+4+1+9+4+4+144+144+100+49+25+4$

$+1+4+16+16+81+81+36+9+1+4+25+25+36+36+100+81+36+16+1$

$+4+49+16+9+9+25+16+4+1+9+16+16+9+36+36+16+9+1+4+16$ $+25+16+16+36+36$

$\mathrm{MSE}=\frac{3516}{100}=35,16$

100

$\mathrm{MSE}=35,16$

PSNR $=10 \log \frac{\mathrm{C}^{2} \max }{M S E}$

PSNR $=10 \log \frac{255}{35,16}$

PSNR $=11,39$

Berdasarkan hasil analisa metode interpolasi fractal dapat disimpulkan bahwasannya pembesaran pada gambar citra ini dapat diperbaiki kualitas citranya dengan memperbesar gambar citra tersebut. MSE dan PSNR ini keduanya merupakan sebuah nilai yang memiliki satuan db (desibels). Semakin rendah nilai MSE maka kualitas citranya semakin baik. Sementara itu, mutu stego-image dikatakan baik jika nilai PSNR $40 \mathrm{db}$ atau lebih.

Nilai intensitas diatas memiliki hasil nilai MSE dan PSNR dapat dilihat hasilnya yang sudah di dapat dengan metode interpolasi fractal yang dimana nilai MSE lebih besar dibandingkan dengan nilai PNSR dikarenakan nilai error yang besar maka akan semakin besar hasilnya, sedangkan nilai error yang kecil akan semakin kecil pula hasilnya.

\section{IMPLEMENTASI}

Hasil merupakan suatu proses dari penyelesaian suatu masalah yang mana masalah ini adalah untuk perbaikan perbesaran kualitas citra Screen Capture CCTV. Ada beberapa masalah yang sering dihadapi ketika sedang melihat video CCTV seperti kurang jelasnya gambar suatu objek atau blur pada gambar video CCTV tersebut, dan akan dilakukan perbaikan dengan Metode Interpolasi Fractal dan akan menghasilkan citra input dan output untuk perbaikan perbesaran kualitas citra Screen Capture CCTV dapat di lihat pada tabel 8 di bawah ini :

Tabel 8 Hasil Metode Interpolasi Fractal Dalam Perbaikan Perbesaran Kualitas Citra Screen Capture CCTV

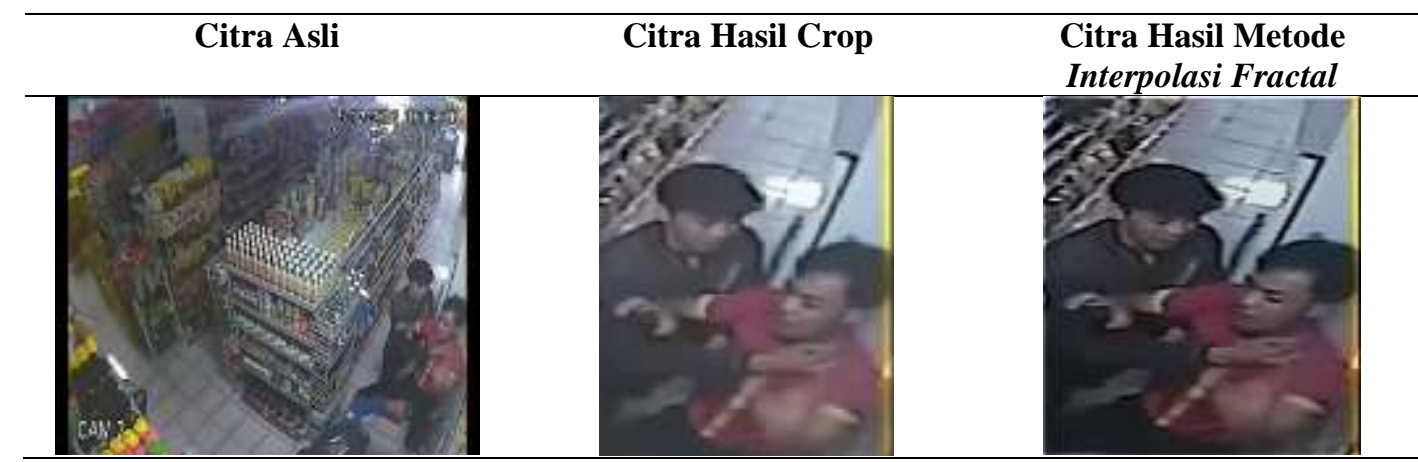


Citra Asli Histogram

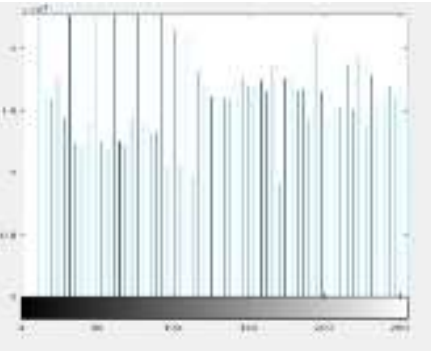

MSE $=1.910$

PSNR $=14.6817$
Histogram Hasil Crop

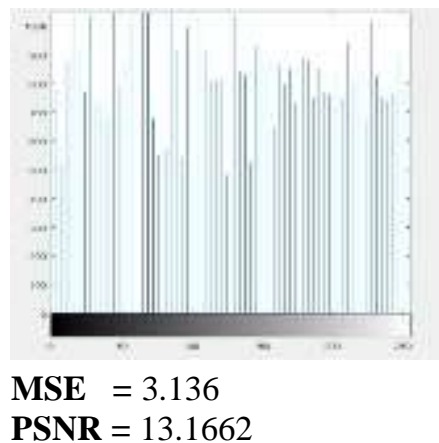

Histogram Metode Interpolasi Fractal

Keterangan :

Dari citra hasil dan histogram dalam perbaikan kualitas citra Screen Capture CCTV dengan menggunakan metode Interpolasi Fractal. Maka hasil yang di dapat dari perbaikan kualitas citra ini yaitu mempunyai kualitas citra yang lebih tajam contras nya dan lebih jelas dibandingkan dengan citra aslinya dan lebih mudah mengenali objek yang telah kita Screen Cpature.

Sedangkan dilihat dari Histogram di atas untuk yang lebih merata nilai intensitasnya itu adalah nilai yang paling bagus, maka nilai Histogram dengan menggunakan metode Interpolasi Fractal ini memiliki nilai intensitas yang merata dibandingkan dengan nilai Histogram lainnya.

Sehingga dapat disimpulkan bahwasannya dalam perbaikan perbesaran kualitas citra Screen Capture CCTV ini menggunakan metode Interpolasi Fractal lebih bagus digunakan dalam hasil analisa yang dilakukan dan memiliki nilai intensitas Histogram yang merata, dengan menggunakan Interpolasi Fractal ini lebih bagus dibandingkan dengan metode lain.

Tampilan pengujian merupakan proses yang bertujuan untuk memastikan apakah semua fungsi sistemnya bekerja dengan baik dan mencari kesalahan yang mungkin terjadi pada sistem. Pada pengujian perbaikan perbesaran kualitas citra Screen Capture CCTV ini terdapat beberapa macam hasil pengujian untuk mendapatkan hasil perbaikan yang baik dengan menggunakan metode Interpolasi Fractal. Dalam pengujian ini citra yang akan diuji yaitu sebuah video record CCTV yang telah di Screen Capture untuk mendapatkan gambar objek tersebut. Yang menggunakan CCTV dari tempat umum seperti di jalan, perusahaan, sekolah, rumah, swalayan/minimarket, Bank, atau video CCTV yang ingin dijadikan sebagai barang bukti untuk anggota aparat yang sedang ingin mencari pelaku tersangka. Adapun hasil pengujian dari beberapa Screen Capture video CCTV yang telah diperbaiki yaitu :

\section{KESIMPULAN}

Adapun kesimpulan yang penulis peroleh bedaraskan hasil dari penelitian ini adalah sebagai berikut :

1. Proses perbesaran citra Screen Capture CCTV yang dilakukan dengan cara penambahan pixel/titik baru yang dilakukan dengan menyisipkan titik-titik tersebut diantara titik yang nilai pixel nya telah dipetakan langsung dari citra.

2. Metode Interpolasi Fractal dapat diterapkan dalam perbesaran citra dengan proses membaca resolusi dengan menyimpanan format citra jpg. Hasil dan pengujian yang didapatkan untuk memperbaiki perbesaran kualitas citra Screen Capture CCTV ini memiliki peningkatan pada nilai rata-rata intensitasnya. Citra yang didapat lebih bagus karena menggunakan metode Interpolasi Fractal. Karena citra dari hasil metode ini memiliki pengaruh yang sangat nyata terhadap kualitas citra hasil perbesaran.

3. Hasil dari pengujian yang didapatkan untuk perbesaran kualitas citra ini juga dilakukan pengujian citra sampai 4 kali uji coba perbesaran dan juga intensitas histogram pencahayaan contrats yang cukup tajam kareana mengalami nilai kecerahan pada citra hasil yang menggunakan metode Interpolasi Fractal.

4. Berdasarkan dari hasil analisa dan pengujian yang di lakukan dalam perbaikan perbesaran kualitas citra Screen Capture CCTV ini dapat disimpulkan bahwasannya metode Interpolasi Fractal ini lebih bagus dan lebih nyata hasilnya. Dalam citra ini hasil dari nilai MSE, PSNR, dan Histogram juga memiliki nilai yang bagus.

\section{REFERENCES}

[1] E. Maryanto, "Identifikasi Nilai Skala Vertikal pada Interpolasi Fractal yang Memaksimalkan Kualitas Citra Hasil Perbesaran ( Identification of Vertical Scale Value of Fractal Interpolation to Maximize Magnified Image Quality ),” vol. II, pp. 183-188, 2013.

[2] H. Nugroho, "Image Enhancement Pada Screen Capture CCTV Dengan Menggunakan Metode Histogram EKualisasi," Kinetik, vol. 2, no. 2, p. 99, 2017.

[3] K. D. Hartomo, "Issn 0853-8697 Implementasi Metode Interpolasi Linear Untuk Pembesaran Resolusi Citra,” Teknoin, vol. 11, no. 3, pp. 219-232, 2006.

[4] S. Aripin and H. Sunandar, "Perancangan Aplikasi Perbaikan Citra Pada Hasil Screenshot Menggunakan Metode Interpolasi Linier," Pelita Inform. Budi Darma, vol. Volume: 1, no. October, pp. 51-58, 2016.

[5] D. Putra, Pengolahan Citra Digital. Yogyakarta: Andi, 2010.

[6] M. Hakobyan, "American University of Armenia College of Science and Engineering Numerical Analysis Project Fractal Interpolation Team: 
JURIKOM (Jurnal Riset Komputer), Vol. 7 No. 1, Februari 2020 e-ISSN 2715-7393 (Media Online), p-ISSN 2407-389X (Media Cetak) DOI 10.30865/jurikom.v7i1.1945 Hal 63-72

Mariam Hakobyan, Gasia Atashian , Hrachya," no. February, 2017.

[7] M. Wi-fi, "BAB 2 LANDASAN TEORI 2.1 Mengenal Wi-Fi," pp. 18-42, 1997.

[8] Sekaring Tyas Widyardini, Pemrograman Matlab untuk Pengolahan Citra Digital: Studi Kasus Sistem Pemantau Ruangan Pengganti CCTV. Universitas Brawijaya Press, 2015. 